\title{
Morphometric Analysis of Foramen Magnum in Adult Dry Skulls in Dakshina Kannada
}

\author{
Ravi Bhaskar ${ }^{1}$, Anjana S. ${ }^{2}$, Satheesha K. S. ${ }^{3}$, Suresh Rao ${ }^{4}$, Naveen Kumar ${ }^{5}$ \\ Tutor $^{1,2}$, Professor ${ }^{3}$, Department of Anatomy, Srinivas Institute of Medical Sciences and \\ Research centre, Mukka, Mangaluru, Karnataka, India, \\ Senior Lecturer \& $\mathrm{Head}^{4}$, Anatomy \& Cell Biology, University of West Indies, \\ Assistant Professor ${ }^{5}$, Department of Anatomy, Manipal Medical College, Manipal. India. \\ E-mail: drravibhaskarr@gmail.com
}

Type of the Paper: Research Article.

Type of Review: Peer Reviewed.

Indexed In: OpenAIRE.

DOI: http://dx.doi.org/10.5281/zenodo.803368.

Google Scholar Citation: IJHSP

How to Cite this Paper:

Ravi Bhaskar., S., Anjana., K. S., Satheesha., Rao, Suresh., \& Kumar, Naveen. (2017). Morphometric Analysis of Foramen Magnum in Adult Dry Skulls in Dakshina Kannada. International Journal of Health Sciences and Pharmacy (IJHSP), 1(1), 45-50.

DOI: http://dx.doi.org/10.5281/zenodo.803368.

International Journal of Health Sciences and Pharmacy (IJHSP)

A Refereed International Journal of Srinivas University, India.

(C) With Authors.

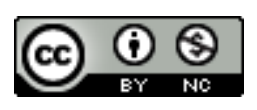

This work is licensed under a Creative Commons Attribution-Non Commercial 4.0 International License subject to proper citation to the publication source of the work.

Disclaimer: The scholarly papers as reviewed and published by the Srinivas Publications (S.P.), India are the views and opinions of their respective authors and are not the views or opinions of the SP. The SP disclaims of any harm or loss caused due to the published content to any party. 


\title{
Morphometric Analysis of Foramen Magnum in Adult Dry Skulls in Dakshina Kannada
}

\author{
Ravi Bhaskar ${ }^{1}$, Anjana S. ${ }^{2}$, Satheesha K. S. ${ }^{3}$, Suresh Rao ${ }^{4}$, Naveen Kumar ${ }^{5}$ \\ Tutor $^{1,2}$, Professor ${ }^{3}$, Department of Anatomy, Srinivas Institute of Medical Sciences and \\ Research centre, Mukka, Mangaluru, Karnataka, India, \\ Senior Lecturer \& $\mathrm{Head}^{4}$, Anatomy \& Cell Biology, University of West Indies, \\ Assistant Professor ${ }^{5}$, Department of Anatomy, Manipal Medical College, Manipal. India. \\ E-mail: drravibhaskarr@gmail.com
}

\begin{abstract}
The objectives of the present study were to determine the type and morphometric measurements of Foramen magnum (FM) in dry human skulls of Dakshina Kannada district of Southern India. Material and Methods: The present study included 50 adult human skulls of which 32 were males and 18 females. The type of foramen magnum observed macroscopically. Antero-posterior (APD) and transverse diameters (TD) were measured by using stainless steel electronic digital callipers. Foramen magnum Index (FMI) was calculated by using formula FMI = APD/TD. Results: Present study observed 4 types of shapes of foramen magnum, among them ovoid type was found higher frequency (48\%). Antero-posterior diameter is a distance between Basion and Opisthion $34.95 \mathrm{~mm}$ in males and $34.58 \mathrm{~mm}$ in females out of $34.81 \mathrm{~mm}$. The transverse diameters $28.66 \mathrm{~mm}$ in males and $28.84 \mathrm{~mm}$ in females out of $28.73 \mathrm{~mm}$. Foramen magnum index $\geq 1.2$ was considered as ovoid and found in 56\% of skulls. Conclusion: We believe that the present study provided additional information about the morphology and morphometric analysis of foramen magnum which is important to radiological, and neurosurgical literature.
\end{abstract}

Keywords: Morphometry, Foramen magnum, Adult dry skull, Dakshina Kannada, India.

\section{INTRODUCTION :}

Cranio-vertebral junction is a complex region during the embryonic developmental process, which involves notochord as an inducer of neuro ectodermal differentiation and paraxial mesoderm as precursor to bone and skeletal muscle [1]. Foramen magnum (FM) is largest foramina in the base of the skull which communicates the posterior cranial fossa with the vertebral canal through which lower part of medulla oblongata, upper part of spinal cord, meninges, vertebral arteries, spinal arteries, accessory nerve. Occasionally tonsil of cerebellum projecting on each side of the brain stem [2]. Knowledge of foramen magnum diameter is important because transverse diameter is more in cases such as Arnold chiari syndrome [3]. Also one who approaches the cranio-vertebral junction surgeries need to know about the morphometric analysis of foramen magnum.

\section{MATERIAL AND METHODS :}

Present study included 50 adult human skulls of which 32 males and 18 females were obtained from the Department of Anatomy Srinivas Institute of Medical Sciences \& Research centre Mukka, Mangaluru. The skulls which exhibited pathological changes and congenital anomalies were excluded from this present study.

Following criteria were followed and studied

1. Four types of shape of the foramen magnum were assessed macroscopically and were photographed (Fig-1). Such as oval, round, tetragonal and hexagonal.

2. Antero-posterior diameter (APD)

3. Transverse diameter (TD)

4. Foramen magnum index (FMI) was calculated by using the formula FMI= $\mathrm{APD} / \mathrm{TD}$ 
Two bony landmarks were identified

Basion: it is a Greek terminology(Greek, basis, a base) [4] the midpoint of anterior margin of foramen magnum of occipital bone opposite the Opisthion. Opisthion is a Greek terminology (Greek -opisthios, posterior) [4] the midpoint on the posterior margin of foramen magnum of occipital bone opposite the basion. Antero-posterior diameter (APD) was calculated as distance between the two points, i.e. basion and Opisthion. Transverse diameter was measured as length of a line drawn perpendicular to the previous line at the point on maximum curvature of lateral margins of foramen magnum of occipital bone. All the measurements were performed by using the stainless steel electronic digital calliper $0-150 \mathrm{~mm}$ with an accuracy of $0.1 \mathrm{~mm}$ and mean and Standard deviation were noted. The data collected tabulated and statistically analysed. Unpaired Mann-Whitney test followed for comparison between the genders. The $\mathrm{p}$ value 0.05 was considered as significant. The measurements were taken thrice by independent observers, in order to reduce the chances of variability of the data and to minimise the bias errors.

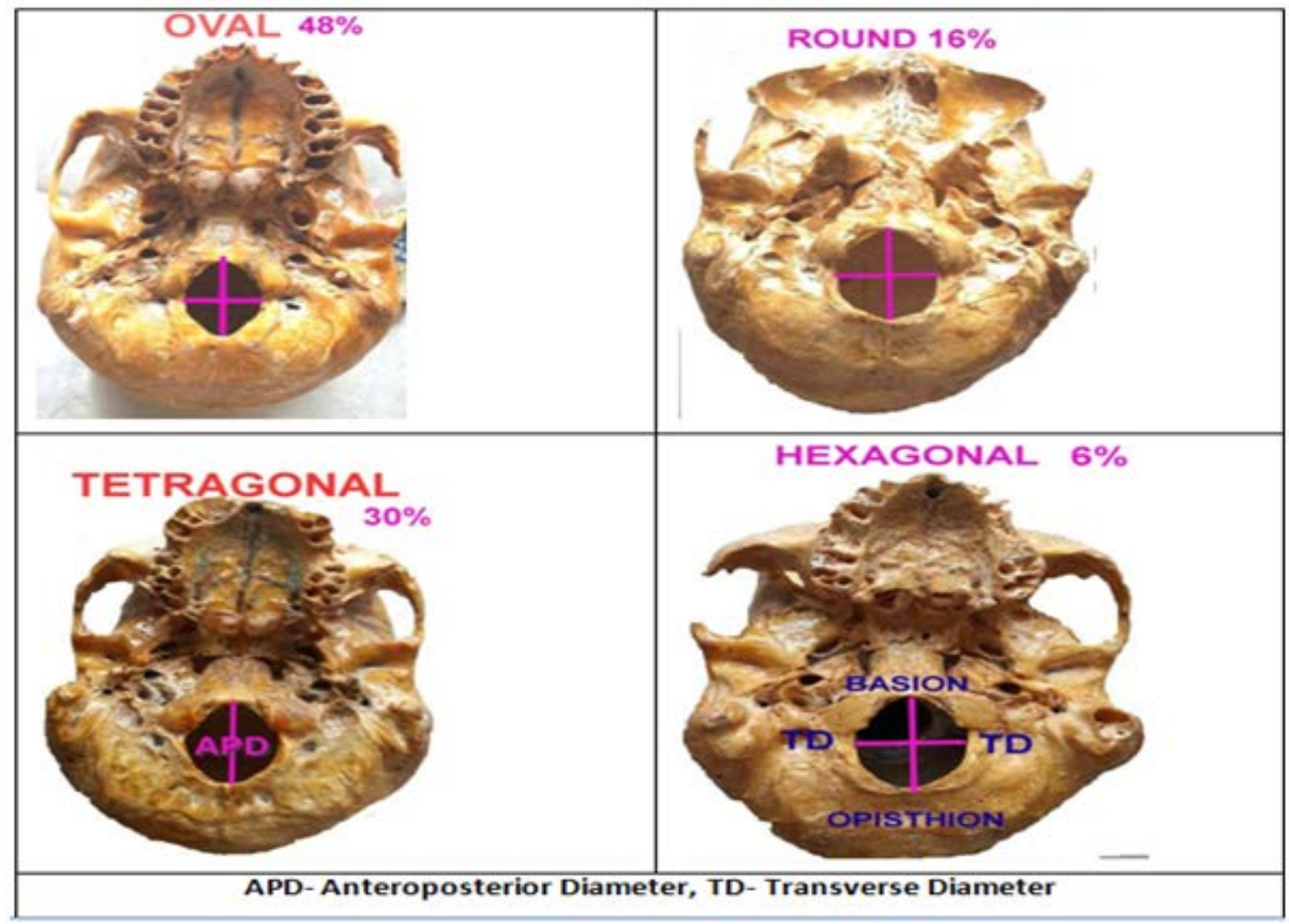

Fig 1: Base of the skull showing the shapes of foramen magnum

\section{OBSERVATION \& RESULTS :}

The present study observed 4 types of shapes of foramen magnum. Among them oval shape was higher in frequency in both male and female as well. This type was found in 16 skulls of males (50\%) and 8 skulls of female (44.44\%), out of 24 skulls (48\%). Round shape was found in 5 skulls of males (15.625\%), 3 skulls of females (16.666) out of 8 skulls (16\%). Tetragonal shape of foramen magnum found in 9 skulls of males (28.125\%) and 6 in Female skulls (33.33\%) out of 15skulls in both the sex (30\%). Hexagonal shape of foramen magnum found in 2 male skulls (6.25\%), 1 in female skull (5.555\%) out of 3 skulls of both the sex (6\%). 
Table 1: Showing the gender wise frequency of types of foramen magnum in present study

\begin{tabular}{|l|l|l|l|l|l|l|}
\hline Shape & MALE & $\mathbf{\%}$ & FEMALE & $\mathbf{\%}$ & TOTAL & \% \\
\hline OVAL & 16 & 50 & 8 & 44.44 & 24 & 48 \\
\hline ROUND & 5 & 15.625 & 3 & 16.666 & 8 & 16 \\
\hline TETRAGONAL & 9 & 28.125 & 6 & 33.333 & 15 & 30 \\
\hline HEXAGONAL & 2 & 6.25 & 1 & 5.555 & 3 & 6 \\
\hline & 32 & $100 \%$ & 18 & $100 \%$ & 50 & $100 \%$ \\
\hline
\end{tabular}

Table 2: Showing the regional comparison of frequency of different types of foramen magnum with present study.

\begin{tabular}{|l|l|l|l|l|l|}
\hline Authors & Population & Oval & Round & Tetragonal & Hexagonal \\
\hline $\begin{array}{l}\text { Keshav Krishna et al } \\
(2016)[5]\end{array}$ & Northern India & $58.8 \%$ & $8.82 \%$ & $17.6 \%$ & $11.8 \%$ \\
\hline $\begin{array}{l}\text { Anil kumar et al } \\
(2015)[6]\end{array}$ & Oman & $50 \%$ & $20 \%$ & $6 \%$ & $8 \%$ \\
\hline $\begin{array}{l}\text { Radhika P.M et al } \\
(2014)[7]\end{array}$ & Southern India & $40 \%$ & $20 \%$ & $6 \%$ & $6 \%$ \\
\hline $\begin{array}{l}\text { Sampada. P.K et al } \\
(2017)[8]\end{array}$ & Southern India & 58 & 9 & 8 & 3 \\
\hline $\begin{array}{l}\text { Present study } \\
\mathbf{n}=50\end{array}$ & $\begin{array}{l}\text { Dakshina Kannada } \\
\text { District of Southern } \\
\text { India }\end{array}$ & $\mathbf{4 8 \%}$ & $\mathbf{1 6 \%}$ & $\mathbf{3 0 \%}$ & $\mathbf{6 \%}$ \\
\hline
\end{tabular}
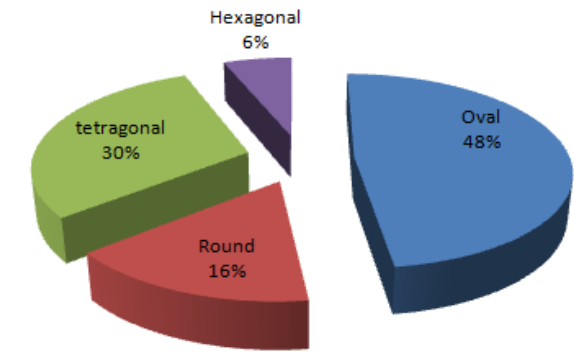

Figure 2: Showing the frequency of the different types of Foramen magnum was observed in the present study $(\mathrm{n}=50)$

Table 3: The Antero-posterior diameter and transvers diameter of foramen magnum in present study $(\mathrm{n}=50)$

\begin{tabular}{|l|l|l|}
\hline & $\begin{array}{l}\text { Antero-Posterior Diameter } \\
(\mathbf{m m})\end{array}$ & $\begin{array}{l}\text { Transverse Diameter } \\
(\mathbf{m m})\end{array}$ \\
\hline Mean & $34.81 \pm 1.79$ & $28.727 \pm 1.37$ \\
\hline SEM & 0.252 & 0.193 \\
\hline Minimum & 30.073 & 24.327 \\
\hline Median & 34.567 & 28.90 \\
\hline Maximum & 39.60 & 31.40 \\
\hline
\end{tabular}

Table 4: The comparison of Antero-posterior and transvers diameter of foramen magnum gender wise in present study

\begin{tabular}{|l|l|l|l|l|}
\hline \multirow{2}{*}{$\begin{array}{l}\text { Measurements } \\
\text { in mm }\end{array}$} & \multicolumn{2}{|c|}{$\begin{array}{c}\text { Antero-Posterior Diameter } \\
\text { (APD) }\end{array}$} & \multicolumn{2}{c|}{$\begin{array}{c}\text { Transverse Diameter } \\
\text { (TD) }\end{array}$} \\
\cline { 2 - 5 } Mean & Male (n=32) & Female (n=18) & Male (n=32) & Female (n=18) \\
\hline SEM & $34.95 \pm 2.05$ & $34.58 \pm 1.20$ & $28.66 \pm 1.42$ & $28.84 \pm 1.32$ \\
\hline
\end{tabular}




\begin{tabular}{|l|l|l|l|l|}
\hline Minimum & 30.07 & 31.55 & 24.40 & 24.33 \\
\hline Median & 34.56 & 34.62 & 29.05 & 28.88 \\
\hline Maximum & 39.6 & 36.99 & 31.40 & 30.56 \\
\hline
\end{tabular}

Table 5: Frequency and percentage of foramen magnum index (FMI)

\begin{tabular}{|c|c|c|c|c|c|c|}
\hline \multirow[b]{2}{*}{$(n=50)$} & \multicolumn{2}{|l|}{ Male } & \multicolumn{2}{|l|}{ Female } & \multicolumn{2}{|l|}{ Total } \\
\hline & $\begin{array}{l}\text { No. of } \\
\text { frequency }\end{array}$ & $\%$ & $\begin{array}{l}\text { No. of } \\
\text { frequency }\end{array}$ & $\%$ & $\begin{array}{l}\text { No. of } \\
\text { frequency }\end{array}$ & $\%$ \\
\hline$<1.20$ & 14 & 43.75 & 08 & 44.44 & 22 & 44 \\
\hline$>1.20$ & 18 & 56.25 & 10 & 55.55 & 28 & 56 \\
\hline Total & 32 & & 18 & & 50 & 100 \\
\hline
\end{tabular}

Table 6: Showing the comparison of Antero-posterior and Transverse diameter of previous studies

\begin{tabular}{|l|l|l|l|}
\hline \multicolumn{1}{|c|}{ Authors } & \multicolumn{1}{|c|}{ Population } & $\begin{array}{l}\text { Antero-posterior } \\
\text { Diameter (APD) }\end{array}$ & \multicolumn{1}{|c|}{$\begin{array}{c}\text { Transverse } \\
\text { Diameter (TD) }\end{array}$} \\
\hline Kizilkant et al (2006) [9] & Turkey & $\mathbf{3 4 . 8}$ & 29.6 \\
\hline Manoel et al (2009) [10] & Brazilian & 35.4 & 29.85 \\
\hline Radhika P M et al (2014) [14] & Southern India & 35.3 & 29.4 \\
\hline Osun woke et al (2012) [11] & Nigerian & 36.1 & 29.5 \\
\hline Sampada P K et al (2017) [8] & Southern India & $\mathbf{3 4 . 8 4}$ & 29.39 \\
\hline Keshav Krishna et al (2016) [5] & Northern India & 34.06 & 27.83 \\
\hline Present study & $\begin{array}{l}\text { Dakshina Kannada } \\
\text { District of Southern } \\
\text { India }\end{array}$ & $\mathbf{3 4 . 8 1}$ & $\mathbf{2 8 . 7 2}$ \\
\hline
\end{tabular}

\section{DISCUSSION :}

It is advisable to have the proper idea about the topography and types of the foramen magnum before approaching the craniovertebral junction surgical procedures. The present study also showed four types of foramen magnum. There are few studies available across the world about the topography and shape of foramen magnum among the different population. In this study the shape of the foramen magnum observed macroscopically and also cross verified with the foramen magnum index. Oval shape is considered when the foramen magnum index is $\geq 1.2$. Present also confirmed the most common type was oval shape (48\%) of FM which is similar to the previous studies. Some of the authors found round shape as most common [12-13].

The comparison of frequency of different types of FM is represented in Table 1 , and Fig.1, 2. In this study also observed the gender wise antero-posterior diameter and transverse diameterfound almost similar to previous studies. Antero-posterior diameter (34.84mm) is similar to Turkish population $34.8 \mathrm{~mm}$ (Kizilkant et al)[9] Southern Indian population
34.84mm(Sampada et al) [8] and almost similar toIndian population35.3mm,(Radhika et al) and 34.06mm [14]. Whereas transverse diameter is similar to Nigerian population $29.5 \mathrm{~mm}$ [11] and almost similar to Indian population 27.83mm (Keshav et al) [5] and 29.4mm [14] (Radhika et al).

Ovoid shape of the foramen magnum has difficult surgical approach to anterior part of the FM. Variations in the morphometry and shape of FM is associated with various clinical problems. Cerebellar tonsillar herniation is associated with larger Antero-posterior diameter [15]. Arnold-chiari malformation is a condition where anomalous development of occiput leads to decreased posterior cranial fossa volume(Osun woke et al).Therefore it is wise to know the exact morphometry and shape of FM during surgical intervention.

\section{CONCLUSION :}

We believe that the present study has provided the additional information about the morphology and morphometric analysis of foramen magnum which is important to the anaesthetists, radiologists, orthopaedists and neurosurgeons, while performing the head and neck/ neurosurgeries. 


\section{REFERENCES :}

[1] R. Shane, Tubbs, Christoph. J. Griessenaures, Marios Loukas, "Morphometric analysis of the foramen magnum: An Anatomic study” Neurosurgery, 2010; vol- 66: pp 385-388.

[2] A. K. Dutta, "Essentials of human Anatomy, Head and Neck," 5th Edition, current books international, Kolkata; 2009.

[3] Sgouros. S., Goldin H. J, Hockely A. D, Wake MJ, et al. "Intracranial volume change in childhood”. J. Neurosurg, 1999;91: pp 610-616.

[4] Vishram Singh, “Anatomy of Head, Neck \& Brain”, Saunders, Churchill Livingstone, Butterworth Heinemann and Hanley, 2009.

[5] Keshav Krishna, AlkaRashmi Nag, Renu Prasad "Morphometric study of foramen magnum and variation in its shape” 2016; vol15 issue 8 ver.IV: pp 120-123.

[6] Anil Kumar, Mitesh Dave, Sanam Anwar "Morphometric evaluation of foramen magnum in dry human skulls” Int. J. Anat Res., 2015; vol 3(2):pp L1015-23.

[7] Radhika P. M, Shailajashetty, Pratap K. J, C. Sheshagiri, Jyoti K.C, "Morphometric study of the foramen magnum in adult human skulls in Indian population” Asian J Med Clin. Sci, 2014: vol-3,issue-2:pp 68-72.

[8] Sampada P. K, Poornima B, Mallikarjun M, Santhosh B Sakri "Morphometric and morphological study of foramen magnum in dried human skull bones”, Int. J. Anat\& Res, 2017; vol5(2.1):pp 36823686.

[9] Kizilkant Emine Dondu, Boyan Neslihan et al. "Morphometry of hypoglossal canal, occipital condyle and foramen magnum" Neurosurgery., 2006; 16(3): pp 121-125.

[10] Manoel. C, Prado F. B., Caria P. H. F., Groppo F. C. "Morphometric analysis of the foramen magnum in human skulls of barazilian individuals: its relation to gender” Braz. J. Morphol. Sci., 2009; 26, 2:pp 104-108.
[11] Osunwoke E. A., Oladipo G. S., Gwunireama I. U., Ngaokere J. O. "Morphometric analysis of the foramen magnum and jugular foramen in a adult skulls in southern Nigerian population. A J. Sc. Ind Res., 2012;3(6): pp 446-448.

[12] MurshedK A, Cicekeibasi A. E., Tuncer I, "Morphometric evaluation of the foramen magnum and variations in its shape: A study of computerised tomographic images of normal adults” Tur J Med Sci., 2003;33: pp 301-306.

[13] Radhakrishna S. K., Sivarama C. H., Ramakrishna A, Bhagya B."Morphometric analysis of foramen magnum for sex determination in south Indian population.” NUJHS, March 2012; 2(1):20-22.

[14] Avic E, Dagtekin A, Ozturk A. H., Kara E, Ozuturk N. C., Uluc $K$ et al "Anaotomical variations of the foramen magnum, occipital condyle and jugular tubercle, Turk Neurosurg, 2011;21(2):181-190.

[15] Standring S Grey's Anatomy: The anatomical basis of clinical practice, $39^{\text {th }}$ Edition, Edinburg; Elsevier Churchill Livingstone, 2005:463-465.

[16] Onar,V. Pazvant, G., GezerInce, N., Alpak, H., Janeczek, M., Kiziltan, Z. "Morphometric analysis of the foramen magnum of byzantine dogs excavated in Istanbul yenikapi at the site of Theodosius harbour”, Med Archaeology and archeometry, 2013; vol.13 no.1:135-142.

[17] Arora Sandeep, Sanjay Kumar Sharma, Sadiq Wadood Siddiqui, Simmi Khatri, "Morphometry and surgical importance of foramen magnum” Int. J. Anat Res., 2017;vol5 (1):3464-69.

[18] Roma Patel, C.D. Mehta, “ Morphometric study of foramen magnum at the base of human skull in south Gujarat”, IOSR Journal of dental and medical sciences, 2014; vol-13, issue-6 Ver.IV:23-25. 